\title{
Nutrient Disorders of ‘Orchestra Pink’ Gloxinia
}

\author{
Paul Cockson, Josh B. Henry, Ingram McCall, \\ and Brian E. Whipker ${ }^{1}$
}

\begin{abstract}
AdDitional INDEX WORDs. deficiency, diagnostics, leaf tissue concentrations, macronutrients, micronutrients, Sinningia speciosa, toxicity

Summary. To produce popular floriculture crops, such as gloxinia (Sinningia speciosa), growers must be equipped with cultural information including the ability to recognize and characterize disorders. Diagnostic criteria for nutrient disorders of gloxinia are absent from current literature. Therefore, gloxinia plants were grown in silica-sand culture to induce, characterize, and photograph symptoms of nutritional disorders. Control plants received a complete modified Hoagland's all-nitrate solution, whereas nutrient-deficient treatments were induced with a complete nutrient formula minus a single nutrient. Boron toxicity was induced by increasing the element 10-fold higher than the complete nutrient formula. We monitored plants continuously to document and photograph sequential series of symptoms as they developed. Typical symptomology of nutrient disorders and critical tissue concentrations are presented. Of 13 treatments, 10 exhibited symptomology; copper, molybdenum, and zinc remained asymptomatic. Symptoms of nitrogen, phosphorus, potassium, magnesium, and sulfur deficiencies, plus boron toxicity manifested early; therefore, these disorders may be more likely problems encountered by growers. Unique symptoms were observed on plants grown in nitrogen, potassium, sulfur, and iron deficient and boron toxic conditions.
\end{abstract}

$\mathrm{G}$ loxinia is native to Brazil and is grown as flowering potted plants (Dole and Wilkins, 2005 ). Growers who wish to produce gloxinia must understand its cultural needs, including fertility requirements. Limited information regarding nutritional requirements of gloxinia is available. Overall recommendations suggest that gloxinia has a low fertility requirement and excessive electrical conductivity (EC) levels should be avoided (Hollis, 1997). Dole and Wilkins (2005) recommend supplying the plants with $150 \mathrm{mg} \cdot \mathrm{L}^{-1}$ nitrogen $(\mathrm{N})$, while maintaining the substrate EC between 1.0 and $1.2 \mathrm{mS} \cdot \mathrm{cm}^{-1}$. Kimmins (1992) recommended applying $200 \mathrm{mg} \cdot \mathrm{L}^{-1} \mathrm{~N}$, but only on a 7 to 10 -d interval. The reported optimal substrate $\mathrm{pH}$ range is reported to be between 5.5 and 6.0 (Dole and Wilkins, 2005; Hamrick, 2003; Kimmins, 1992), and high substrate $\mathrm{pH}$ induced iron (Fe) deficiencies have been observed by the authors when the substrate $\mathrm{pH}$ exceeded 6.5. Growers are also cautioned to avoid excessive levels of ammoniacalnitrogen, especially during winter production, as ammonium toxicity

Department of Horticultural Science, 2721 Founders Drive, P.O. Box 7609, North Carolina State University, Raleigh, NC 27695-7609.

${ }^{1}$ Corresponding author. E-mail: bwhipker@ncsu.edu. doi: 10.21273/HORTTECH03833-17 can occur (Hamrick, 2003; Hollis, 1997). Avoiding excessive levels of phosphorus $(\mathrm{P})$ is also recommended (Hamrick, 2003; Hollis, 1997). Reported boron (B) deficiency symptoms include the loss of the apical meristem and development of thicker, distorted younger leaves (Love, 1985). Symptomology of other gloxinia nutrient disorders have not been published.

Growers producing gloxinia can encounter problems if nutritional disorders manifest because they lack the resources to accurately identify specific disorders. Tissue nutrient sufficiency ranges for gloxinia are available (Bryson and Mills, 2014; Cresswell and Weir, 1997; Dole and Wilkins, 2005), but there are not specific guidelines for critical tissue nutrient values when an element is deficient. To evaluate crops for the unique symptoms of gloxinia nutrient disorders, it is important that plants be grown under nutrient-stress conditions. The information gleaned from such species-specific studies adds information to the grower's toolbox of diagnostic criterion. These diagnostic tools include symptomology descriptions, images of the disorders, and critical tissue nutrient concentrations. The objective of this study was to characterize the symptomology of gloxinia nutritional disorders and to determine critical nutrient levels of the crop.

\section{Materials and methods}

'Orchestra Pink' gloxinia plugs in 84 -cell $(2.8 \times 2.8 \times 3.8 \mathrm{~cm}$ cell size $)$ plug trays were received from a commercial propagator (C. Raker and Sons, Litchfield, MI) were transplanted into 5.5 -inch-diameter $(0.76$ $\mathrm{L}$ volume) plastic pots containing acid-washed silica sand [Millersville \#2 (0.8-1.2 mm diameter); Southern Products and Silica Co., Hoffman, NC] on 10 Mar. 2016. The experiment was conducted in a glass-glazed greenhouse at North Carolina State University, Raleigh, NC (lat. $35^{\circ} \mathrm{N}$ ). Plants were grown at $22^{\circ} \mathrm{C}$ day and $18^{\circ} \mathrm{C}$ night air temperature set points under ambient daylight and natural photoperiod.

Treatments started immediately upon transplanting into an automated, recirculating irrigation system constructed out of 4-inch-diameter polyvinyl chloride (PVC) pipe (Charlotte Plastics, Charlotte, NC). The system consisted of 18 separate irrigation lines (each $6 \mathrm{ft}$ long). Each line had eight openings on the top that contained PVC funnels with 5.5inch-diameter openings that held the eight pots for the elemental treatment. Thirteen lines contained the disorder treatments, and five lines contained the control treatments.

\begin{tabular}{llll}
\hline $\begin{array}{l}\text { Units } \\
\text { To convert U.S. to SI, } \\
\text { multiply by }\end{array}$ & U.S. unit & SI unit & $\begin{array}{l}\text { To convert SI to U.S., } \\
\text { multiply by }\end{array}$ \\
\hline 0.3048 & $\mathrm{ft}$ & $\mathrm{m}$ & 3.2808 \\
3.7854 & $\mathrm{gal}$ & $\mathrm{L}$ & 0.2642 \\
2.54 & inch $(\mathrm{es})$ & $\mathrm{cm}$ & 0.3937 \\
25.4 & inch(es) & $\mathrm{mm}$ & 0.0394 \\
1 & $\mathrm{mmho} / \mathrm{cm}$ & $\mathrm{mS} \cdot \mathrm{cm}^{-1}$ & 1 \\
28.3495 & $\mathrm{oz}$ & $\mathrm{g}$ & 0.0353 \\
1 & $\mathrm{ppm}$ & $\mathrm{mg} \cdot \mathrm{kg}^{-1}$ & 1 \\
1 & $\mathrm{ppm}$ & $\mathrm{mg} \cdot \mathrm{L}^{-1}$ & 1 \\
$\left({ }^{\circ} \mathrm{F}-32\right) \div 1.8$ & ${ }^{\circ} \mathrm{F}$ & ${ }^{\circ} \mathrm{C}$ & $\left({ }^{\circ} \mathrm{C} \times 1.8\right)+32$
\end{tabular}


Pipes were randomly assigned as a control or disorder after the system was constructed. Control plants were grown with a complete modified Hoagland's all-nitrate solution consisting of (macronutrient concentrations) $15 \mathrm{~mm}$ nitrate-nitrogen $\left(\mathrm{NO}_{3}^{-}\right)$, $1.0 \mathrm{~mm}$ phosphate-phosphorus $\left(\mathrm{H}_{2} \mathrm{PO}_{4}^{-}\right), 6.0 \mathrm{~mm}$ potassium $\left(\mathrm{K}^{+}\right)$, $5.0 \mathrm{~mm}$ calcium $\left(\mathrm{Ca}^{2+}\right), 2.0 \mathrm{~mm}$ magnesium $\left(\mathrm{Mg}^{2+}\right)$, and $2.0 \mathrm{~mm}$ sulfatesulfur $\left(\mathrm{SO}_{4}{ }^{2-}\right)$ (Hoagland and Arnon, 1950); plus (micronutrient concentrations) $72 \mu \mathrm{M}$ iron $\left(\mathrm{Fe}^{2+}\right), 18 \mu \mathrm{M}$ manganese $\left(\mathrm{Mn}^{2+}\right), 3 \mu \mathrm{M}$ copper $\left(\mathrm{Cu}^{2+}\right)$, $3 \mu \mathrm{M}$ zinc $\left(\mathrm{Zn}^{2+}\right), 45 \mu \mathrm{M}$ boron $\left(\mathrm{BO}_{3}{ }^{3-}\right)$, and $0.1 \mu \mathrm{M}$ molybdenum $\left(\mathrm{MoO}_{4}{ }^{2-}\right)$. To induce nutrient-deficient treatments, the plants were irrigated with complete nutrient solution excluding one of the nutrients. The B-toxicity treatment was conducted by increasing the $\mathrm{B}$ concentration to $450 \mu \mathrm{M}$ in the Hoagland's solution. Detailed information about formulation of the fertilizer treatments and the salts used can be found in Barnes et al. (2012).

Irrigation was automated using a drip system equipped with sumppumps (model 1A; Little Giant Pump Co., Oklahoma City, OK) and plastic drip emitters (Stuppy, North Kansas
City, MO). The irrigation frequency was adjusted to maintain plant turgidity so plants were never water stressed; on average irrigation occurred once every $3 \mathrm{~h}$ from 0600 to $1800 \mathrm{HR}$. Leachate from the container was captured and recirculated. Nutrient solutions were replaced weekly. Plants were monitored daily to document and photograph sequential series of symptoms by chronological age of plant development (youngest, young, recently mature, and/or mature leaves).

When initial symptoms occurred for each treatment, three plants were selected for tissue sampling. The remaining five plants were grown to document advanced symptomology. Recently matured, fully expanded leaves were sampled to quantify the critical tissue concentration for each element. Harvested leaves were initially rinsed with deionized water, then washed in a solution of $0.5 \mathrm{~N}$ $\mathrm{HCl}$ for $1 \mathrm{~min}$ and again rinsed with deionized water. The remaining shoot tissue was excised at the substrate surface and the roots were discarded. Leaf and whole-plant tissue were dried at $70{ }^{\circ} \mathrm{C}$ for at least $\mathrm{l}$ week, and the dry weight values were recorded (Table 1). Tissue samples from three single plant replicates were then ground using a tissue mill (Thomas Wiley ${ }^{\circledR}$ Mini-Mill; Thomas Scientific, Swedesboro, NJ) to pass a $\leq 0.5-\mathrm{mm}$ sieve and analyzed for nutrient content by AgSource Laboratories (Lincoln, $\mathrm{NE}$ ). Total $\mathrm{N}$ was processed by Kjeldahl digestion and determined via flow injection analysis. Extractable $\mathrm{K}$ was processed by $2 \%$ acetic acid digestion and determined via inductively coupled plasma mass spectrometry (ICP-MS). Total $\mathrm{P}$ and all other plant minerals were processed by nitric acid/hydrogen peroxide digestion and determined via ICP-MS.

The experiment was ended on 6 July 2016. At termination, the treatments that were symptomless $(\mathrm{Cu}, \mathrm{Mo}$, and $\mathrm{Zn})$ were sampled for shoot dry weight and nutrient levels. Data were analyzed with SAS (version 9.4; SAS Institute, Cary, NC) and subjected to analysis of variance (ANOVA) using PROC ANOVA. Where $F$-tests indicated evidence of significant differences among means, least significant difference $(P \leq 0.05)$ were used. Tissue concentration values obtained from this experiment were compared with optimum values (Table 1) published by Cresswell and Weir (1997) for gloxinia.

Table 1. 'Orchestra Pink' gloxinia plant dry weight and nutrient concentrations as affected by deficient or toxic nutrient treatments are reported in comparison with the complete control that was harvested at the time symptoms were observed.

\begin{tabular}{|c|c|c|c|c|c|c|c|c|c|c|c|c|c|}
\hline \multirow[b]{2}{*}{ Treatment } & $-\mathbf{N}^{\mathrm{z}}$ & $-\mathbf{P}$ & $-\mathbf{K}$ & $-\mathrm{Ca}$ & $-M g$ & $-S$ & $-\mathbf{B}^{\mathbf{y}}$ & $++B^{y}$ & $-\mathbf{C u}$ & $-\mathrm{Fe}$ & $-M n$ & - Mo & $-\mathbf{Z n}$ \\
\hline & \multicolumn{13}{|c|}{ Dry wt $(g)^{x}$} \\
\hline Element & $\mathrm{N}$ & $\mathrm{P}$ & $\mathrm{K}$ & $\mathrm{Ca}$ & $\mathrm{Mg}$ & $S$ & B & B & $\mathrm{Cu}$ & $\mathrm{Fe}$ & $\mathrm{Mn}$ & Mo & $\mathrm{Zn}$ \\
\hline Treatment & 0.27 & 1.34 & 0.63 & 6.44 & 2.44 & 0.98 & 1.28 & 0.61 & 11.67 & 1.87 & 2.10 & 17.00 & 11.10 \\
\hline \multirow[t]{2}{*}{$P$ value $^{\mathrm{w}}$} & $* * *$ & * & * & NS & NS & NS & * & * & NS & NS & NS & NS & NS \\
\hline & \multicolumn{6}{|c|}{ Tissue nutrient concn (\%) } & \multicolumn{7}{|c|}{ Tissue nutrient concn $\left(\mathrm{mg} \cdot \mathrm{kg}^{-1}\right)^{\mathrm{x}}$} \\
\hline Control & 3.75 & 0.32 & 5.59 & 2.54 & 0.43 & 0.25 & 82.0 & 82.0 & 11.0 & 77.9 & 53.4 & $9.28^{\mathrm{v}}$ & 20.2 \\
\hline Treatment & 0.97 & 0.06 & 0.29 & 0.22 & 0.15 & 0.12 & 19.9 & 848.3 & 5.9 & 47.4 & 12.1 & 0.01 & 11.6 \\
\hline$P$ value & $* * *$ & $* * *$ & $* * *$ & *** & ** & *** & $* * *$ & $* * *$ & ** & * & $* * *$ & * & ** \\
\hline \multicolumn{14}{|c|}{ Comparison tissue values $^{\mathrm{u}}$} \\
\hline & \multicolumn{6}{|c|}{ Tissue nutrient concn (\%) } & \multicolumn{7}{|c|}{ Tissue nutrient concn $\left(\mathrm{mg} \cdot \mathrm{kg}^{-1}\right)$} \\
\hline
\end{tabular}




\section{Results}

Of 13 nutrient disorder treatments, 10 exhibited visual symptomology. Symptoms and shoot dry weight values were reported (Table 1). Values for percentage difference in shoot dry weight values were presented in the text if control and treatment tissues were significantly different when symptoms first appeared. Unless otherwise noted, values for tissue concentrations presented were significantly different.

Nitrogen. Plants grown under $\mathrm{N}$-deficient conditions became chlorotic (Fig. 1A) and had $71 \%$ less dry weight than control plants (Table 1). The control tissue $\mathrm{N}$ concentration was $3.75 \%$, whereas tissue concentrations from plants grown under $\mathrm{N}$-deficient conditions were $0.97 \%$ (Table 1). As the disorder progressed, the chlorotic coloration developed into a vibrant yellow, and the newer leaf centers were amber in coloration (Fig. 1B). Lower leaves continued to yellow, becoming a light tan, before eventually becoming completely necrotic. The necrotic areas advanced inward on the older foliage, whereas the newer leaves experienced yellowing of the margins. In the advanced stages, the upper leaves also became partially necrotic, whereas lower leaves were completely necrotic.

Phosphorus. Deficiency of $\mathrm{P}$ manifested on lower leaves as a chlorosis of the leaf margin accompanied by a darker green coloration in the new growth. Plants grown under P-deficient conditions had $43 \%$ less dry weight than those receiving $\mathrm{P}$ (Table 1). Control plants had a concentration of $0.32 \% \mathrm{P}$, and plants grown under P-deficient conditions had a concentration of $0.06 \% \mathrm{P}$ (Table 1). As symptoms progressed, affected lower leaves developed a dark coloration across the surface, which resembled a dark purple burning or scabbing. Advanced symptoms resulted in the middle leaves developing marginal tan spotting.

Potassium. Plants grown without $\mathrm{K}$ showed symptoms of stunted growth and the new leaves were thicker with a tan necrotic margin. K-deficient plants had 32\% less dry weight than the control plants ( $\mathrm{Ta}$ ble 1 ). The tissue $\mathrm{K}$ concentrations of control plants and plants grown under a K-deficient fertilization regiment were $5.59 \%$ and $0.29 \%$, respectively (Table 1). Over time, the lower leaves exhibited a veinal chlorosis resulting in a green leaf with tan to yellow venation (Fig. 2A). In advanced stages, necrotic spots developed on the lower foliage (Fig. 2B).

Calcium. Young leaves on plants grown under $\mathrm{Ca}$-deficient conditions exhibited dark brown necrotic spots on the leaf tip and curled downward at the margins. The new leaves also
NITROGEN DEFICIENCY
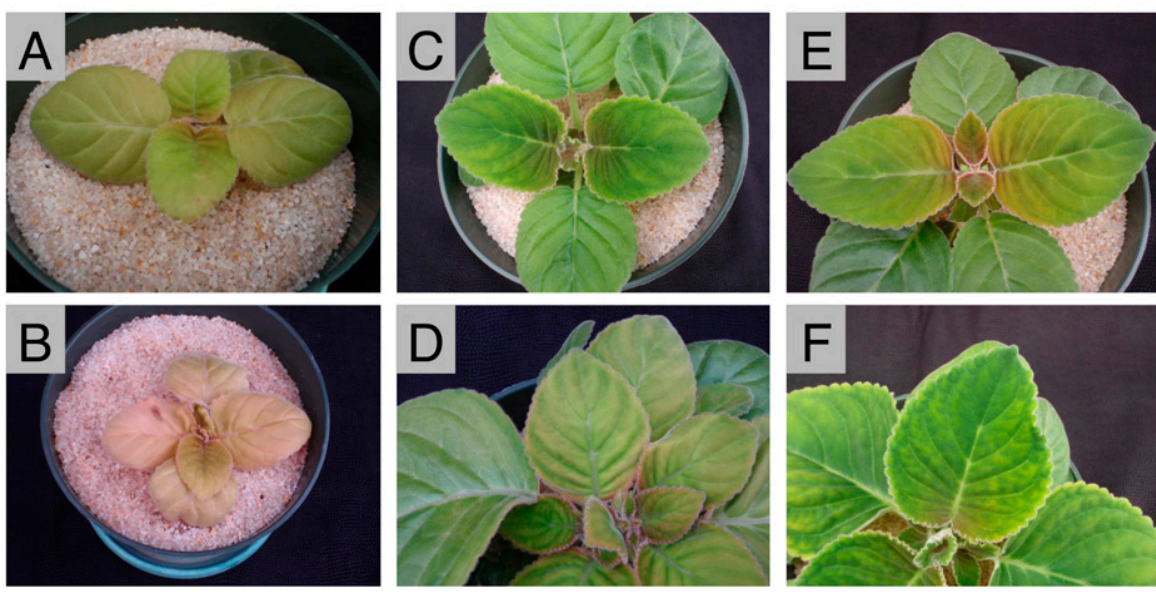

Fig. 1. Amber coloration associated with nitrogen $(\mathrm{N})$, sulfur $(\mathrm{S})$, and iron $(\mathrm{Fe})$ deficiencies of 'Orchestra Pink' gloxinia. Initial symptomology is shown in the top row, whereas more advanced symptomology appears on the bottom row. With $\mathrm{N}$ deficiency, plant size is smaller than the control (A) and the leaves develop a bright yellow coloration on the older tissue (B). The development of S deficiency symptoms occurs on plants with less effect on plant growth (C) and the leaf yellowing occurs on the upper foliage (D). Symptoms of Fe deficiency developed as an overall leaf yellowing $(\mathrm{E})$ and interveinal chlorosis $(\mathrm{F})$. exhibited stunted development and deformation. Over time, the new leaves became necrotic and turned brown. The flowers produced were stunted, had necrotic spots, never fully developed, or died as compared with the controls. Plants grown without Ca were similar in dry weight to those plants that received a complete fertilizer regiment at the time when initial symptoms developed (Table 1). Control plants had a Ca concentration of $2.54 \%$, whereas plants grown without $\mathrm{Ca}$ had a concentration of $0.22 \% \mathrm{Ca}$ (Table 1). In advanced stages of $\mathrm{Ca}$ deficiency, the apical bud became necrotic, and plant death followed.

Magnesium. Plants grown under $\mathrm{Mg}$-deficient conditions first exhibited chlorosis of the interveinal regions of the middle and lower leaves. Magnesium tissue concentrations were significantly different, with control plants containing $0.43 \% \mathrm{Mg}$ compared with $0.15 \% \mathrm{Mg}$ for $\mathrm{Mg}$-deficient plants (Table 1). As the disorder progressed, interveinal necrosis developed on the middle and lower leaves. In more severe cases, the lower leaves exhibited a tan necrosis along the leaf margin as well.

Sulfur. Initially, plants grown under conditions of $S$ deficiency developed a greenish-chlorotic coloration and were stunted. Early $S$ deprivation then manifested as a light amber coloration on the new foliage concentrated at the basal margin (Fig. 1C). Plants exhibiting $\mathrm{S}$ deficiency symptoms were similar in dry weight compared with the control (Table 1). However, tissue concentrations were significantly different; control tissue contained $0.25 \% \mathrm{~S}$, whereas the tissue of plants grown without $S$ had $0.12 \% S$ (Table 1). As $S$ deficiency progressed, greenishchlorotic coloration intensified to chlorosis in the middle and upper foliage (Fig. 1D). Middle leaves then began to develop a marginal, interveinal necrosis in conjunction with an eventual overall pale coloration.

Boron. Deficiency symptoms initially manifested in the younger leaves. Leaves were straplike and smaller with tan specks scattered on the mid and upper leaf surfaces. Boron-deficient plants had 39\% more dry weight when compared with the controls (Table 1). Control tissue contained $82.0 \mathrm{mg} \cdot \mathrm{kg}^{-1} \mathrm{~B}$, and tissue 
from plants grown under B-deficient conditions contained $19.9 \mathrm{mg} \cdot \mathrm{kg}^{-1} \mathrm{~B}$ (Table 1). As the disorder progressed, the tan specks expanded into larger dark brown or black regions on the middle and upper foliage. Lower axillaryshoot buds eventually died, followed by the apical bud. Flowers and flower stalks developed but were severely stunted and never opened when compared with the controls.

Boron toxicity symptoms first manifested on the lower leaves as marginal, necrotic brown spots (Fig. $3 \mathrm{~A})$. Dry weight of the control plants were $51 \%$ greater than plants grown under $\mathrm{B}$ toxic conditions (Table $\mathrm{l}$ ). The control tissue $\mathrm{B}$ concentration was $82 \mathrm{mg} \cdot \mathrm{kg}^{-1}$, whereas the B toxicity tissue concentration was 10 times higher at $848.3 \mathrm{mg} \cdot \mathrm{kg}^{-1}$ (Table $\mathrm{l}$ ). As the disorder progressed, the brown spots spread along the margin of lower leaves and onto the newer growth. The leaf marginal spotting developed in the middle and upper leaves. Upward cupping and inward curling of the affected leaves were observed (Fig. 3B). Advanced toxicity symptoms resulted in severe wrinkling of the mid and lower leaf surface in conjunction with marginal upward cupping. Flower buds developed, but the base of the flower became necrotic and died before reaching full maturity. Eventually the lower leaves developed severe necrosis.

Iron. The first symptom of Fe deficiency was the development of a pale green coloration on the upper foliage. The early chlorosis was difficult to detect without the aid of a control; however, the newest growth later exhibited an amber coloration at the base and margin of the leaves much like $\mathrm{N}$ and $\mathrm{S}$ deficiency (Fig. $\mathrm{IE}$ ). Dry weight of control plants and plants grown without Fe were similar (Table 1). The Fe concentration of control plants was $77.9 \mathrm{mg} \cdot \mathrm{kg}^{-1}$, whereas plants grown under Fedeficient conditions had a concentration of $47.4 \mathrm{mg} \cdot \mathrm{kg}^{-1}$ (Table 1 ). As the disorder progressed some upper leaves developed an interveinal chlorosis first on the leaf margin which then progressed in and downward toward the midrib (Fig. IF). With advanced symptomology, the interveinal chlorosis became more severe and resulted in a stark bleached coloration between the veins of the mid and upper leaves.
Manganese. Plants grown without $\mathrm{Mn}$ initially developed an interveinal chlorosis of the mid and upper-foliage. Dry weight from the control treatment plants and plants grown under Mn-deficient conditions were not significantly different (Table 1). Control tissue had a Mn concentration of $53.4 \mathrm{mg} \cdot \mathrm{kg}^{-1}$, and plants grown under Mn-deficient conditions contained $12.1 \mathrm{mg} \cdot \mathrm{kg}^{-1}$ Mn (Table 1). The pale-chlorotic coloration intensified to interveinal chlorosis in most of the central leaves. Symptoms intensified in advanced stages and became more pronounced on the middle leaves as they expanded inward toward the petiole.

Copper, MOlybdenum, AND zINC. After 17 weeks of growth, plants grown in the absence of $\mathrm{Cu}$, molybdenum (Mo), and $\mathrm{Zn}$ exhibited no distinct visual symptoms. The experiment was ended, and these asymptomatic plants were sampled and analyzed for dry weight and tissue concentrations to determine if nonvisual differences were evident. There were no significant difference in dry weight between control plants and those grown under $\mathrm{Cu}, \mathrm{Mo}$, or Zn-deficient conditions (Table 1 ). Copper tissue concentrations in control plants were $11.0 \mathrm{mg} \cdot \mathrm{kg}^{-1}$, whereas plants grown without $\mathrm{Cu}$ had $5.9 \mathrm{mg} \cdot \mathrm{kg}^{-1}$ (Table 1). Molybdenum tissue levels were 9.28 and 0.01 $\mathrm{mg} \cdot \mathrm{kg}^{-1}$, for the control and $\mathrm{Mo}-$ deficient plants, respectively (significant at $P \leq 0.06)$. The control tissue $\mathrm{Zn}$ concentration was $20.2 \mathrm{mg} \cdot \mathrm{kg}^{-1}$, whereas the tissue concentration in plants grown without $\mathrm{Zn}$ was 11.6 $\mathrm{mg} \cdot \mathrm{kg}^{-1}$ (Table 1). Although visual symptoms did not develop, the corresponding tissue values can be used as indicators of the lower nutrient sufficiency ranges.

\section{Discussion}

The observed symptoms of $\mathrm{Ca}$, $\mathrm{P}, \mathrm{Mg}$, and $\mathrm{Mn}$ deficiencies matched descriptions from current literature for most species (Barker and Pilbeam, 2007; Gibson et al., 2007). A Zn concentration of $11.6 \mathrm{mg} \cdot \mathrm{kg}^{-1} \mathrm{oc}-$ curred in this study, which was lower than the $18-19 \mathrm{mg} \cdot \mathrm{kg}^{-1} \mathrm{Zn}$ range suggested by Cresswell and Weir (1997). Because Zn-deficient gloxinia was asymptomatic, the critical nutrient concentration may be modified to $12 \mathrm{mg} \cdot \mathrm{kg}^{-1}$. For $\mathrm{Cu}, \mathrm{Mo}$, and
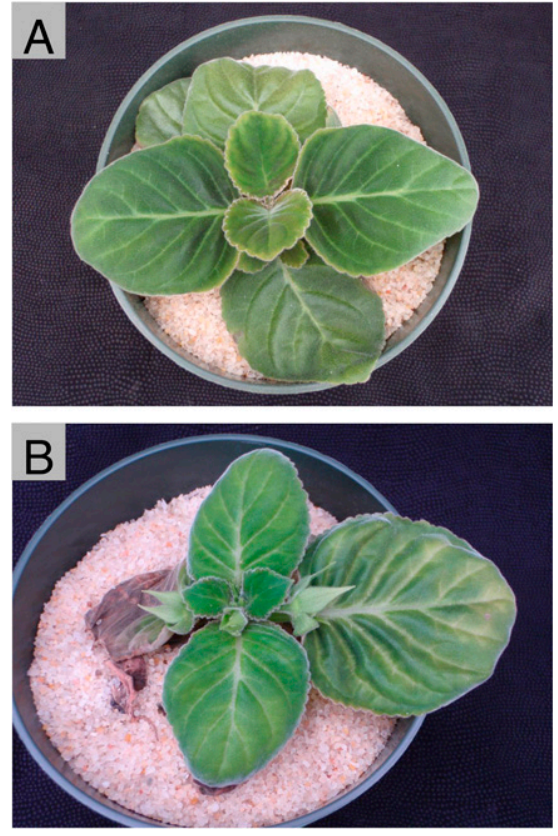

Fig. 2. Initial veinal chlorosis (A) and more extensive advanced veinal chlorosis (B) on potassium deficient leaves of 'Orchestra Pink' gloxinia.
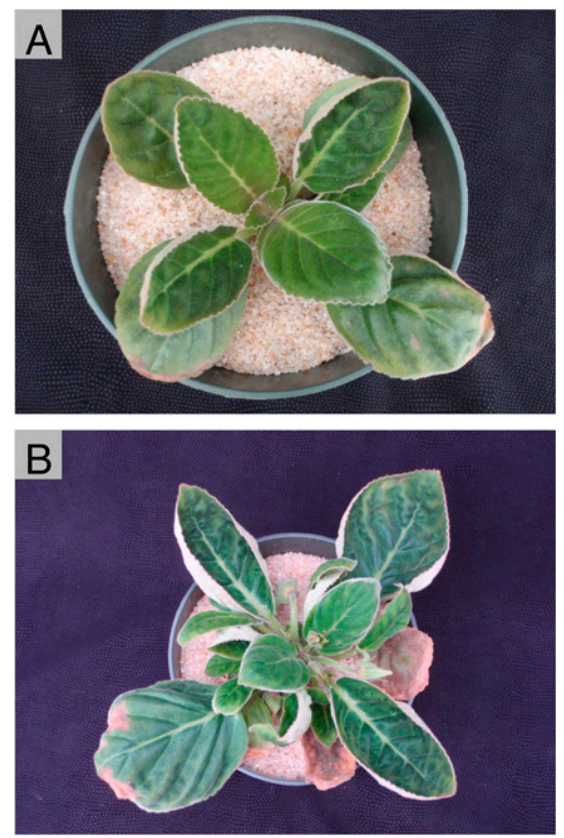

Fig. 3. Initial cupping (A) of the leaf margin due to boron toxicity in 'Orchestra Pink' gloxinia. Over time, leaf cupping becomes more pronounced and marginal leaf necrosis also develops (B).

$\mathrm{Zn}$ deficiency treatments, symptoms may not have been manifested due to low sensitivity to these disorders, or alternatively, the plug substrate provided adequate nutrient levels. The 
tissue values associated with $\mathrm{Cu}, \mathrm{Mo}$, and $\mathrm{Zn}$ deficiencies (Table 1 ) can be used by growers to aid in early detection of nutritional problems.

For N, K, S, and Fe deficiency and $\mathrm{B}$ toxicity, we observed symptoms that were not yet identified in literature for gloxinia. Nitrogen, S, and Fedeficient plants exhibited an amber coloration around the base and margin of the new foliage (Fig. 1). These symptoms have been observed on wax begonia (Begonia semperflorenscultorum) for $\mathrm{N}$ deficiency, and with Fe deficiency of ornamental cabbage [Brassica oleracea var. acephala (Gibson et al., 2007)]. For plants grown under K-deficient conditions, we observed a venial chlorosis, which resulted in tan to yellow veins with green interveinal regions (Fig. 2). Boron toxicity developed symptoms of marginal necrosis as well as a severe upward cupping of the middle foliage (Fig. 3). The tissue values for B toxicity were 10 times greater than the control. These unique symptoms support a species-specific approach for visual diagnosis of nutrient disorders because of the possibility of misidentification.

Boron deficiency exhibited typical symptomology, yet the B-deficient plant had 39\% more dry weight when compared with the control. This increase of weight could be the result of increased axillary shoots as a result of apical meristem termination. Bouma (1969) studied the effect of growing subterranean clover (Trifolium subterraneum) initially with a half strength $\mathrm{B}$ solution $(0.001,0.002,0.004$, or $\left.0.032 \mathrm{mg} \cdot \mathrm{L}^{-1}\right)$ for $7 \mathrm{~d}$ and then each $\mathrm{B}$ concentration was doubled for the next $7 \mathrm{~d}$. Seedlings were then transferred into another container with the same complete fertilizer solutions containing either $0,0.002,0.004$, 0.008 , or $0.064 \mathrm{mg} \cdot \mathrm{L}^{-1} \mathrm{~B}$. While Bouma (1969) reported a greater trend of increased shoot dry weight as compared with root dry weight when B was withheld, there was not a corresponding increase in shoot dry weight overall.

In addition, studies with over 30 plant species (Barnes, 2010; Pitchay, 2003; Williams, 2004) demonstrated similar trends with shoot dry weight not being affected. Of the 30 species, only one ['Gartenmeister Bonstedt' fuchsia (Fuchsia bybrid)] had Bdeficient plants with greater weight than the control. Under B-deficient conditions, some plants may have a greater tendency to develop more axillary shoots when the growing tip dies (Gibson et al., 2007). For gloxinia, this increase in dry weight may be attributed to the increased proliferation of fleshy axillary shoots being of greater dry weight than the inflorescences that develop on the control plants.

When the control and deficient treatment tissue concentrations were compared with optimum ranges and values reported by Cresswell and Weir (1997), some differences were observed (Table 1). For the deficient plants, $\mathrm{Mg}, \mathrm{Cu}$, and $\mathrm{Fe}$ fell within the low range of acceptable values; however, N, P, K, Ca, S, B, Mn, and $\mathrm{Zn}$ concentrations were below the low range values they reported. In addition, the $\mathrm{B}$ toxicity concentration exceeds the sufficiency values they reported. This study provides the first tissue values for Mo in gloxinia, and provide guidelines for interpreting the lower critical tissue concentrations.

\section{Conclusion}

Nitrogen, P, K, Mg, and S deficiency and B toxicity symptoms were first to manifest on gloxinia. This early manifestation indicates that growers should closely monitor these elements. An amber coloration was observed at the base of the youngest growth of $\mathrm{N}, \mathrm{S}$, and Fe deficient plants. This species-specific indicator will be useful in helping to accurately diagnose nutritional disorders. Potassium deficiency also exhibited unique symptomology as a reverse veinal chlorosis on the lower foliage. Boron toxicity manifested as a cupping of the leaf margin. Given the deficit of information regarding gloxinia nutritional deficiencies, the research presented here will contribute to gloxinia production guidelines. The symptoms observed here reinforce the importance of species-specific diagnosis of nutritional disorders. This information will assist growers in the diagnosis of nutritional disorders in the production and management of gloxinia as well as add to the greater nutritional diagnostic literature.

\section{Literature cited}

Barker, A.V. and D.J. Pilbeam. 2007. Handbook of plant nutrition. CRC Press, Boca Raton, FL.
Barnes, J. 2010. Characterization of nutrient disorders of floriculture species. North Carolina State Univ., Raleigh, MS Thesis. I May 2017. <http://www.lib. ncsu.edu/resolver/1840.16/6025>.

Barnes, J., B. Whipker, I. McCall, and J. Frantz. 2012. Nutrient disorders of 'Evolution' mealy-cup sage. HortTechnology 22:502-508.

Bouma, D. 1969. Effects of changes in boron nutrition on growth and development of subterranean clover. Austral. J. Biol. Sci. 22:523-534.

Bryson, G.M. and H.A. Mills. 2014. Plant analysis handbook IV. Micro-Macro Publ., Athens, GA.

Cresswell, G.C. and R.G. Weir. 1997. Plant nutrient disorders 5: Ornamental plants and shrubs. Inkata Press, Melbourne, Australia.

Dole, J.M. and H.F. Wilkins. 2005. Floriculture principles and species. 2 nd ed. Pearson-Prentice Hall, Upper Saddle River, NJ.

Gibson, J.L., D.S. Pitchay, A.L. WilliamsRhodes, B.E. Whipker, P.V. Nelson, and J.M. Dole. 2007. Nutrient deficiencies in bedding plants. Ball Publ., Batavia, IL.

Hamrick, D. 2003. Ball redbook. Vol. 2. 17th ed. Ball Publ., West Chicago, IL.

Hoagland, R.J. and D.I. Arnon. 1950. The water-culture method for growing plants without soil. California Agr. Expt. Sta. Circ. 347. Revised ed.

Hollis, R.P. 1997. Gloxinia, p. 70-77. In: M.L. Gaston, S.A. Carver, C.A. Irwin, and R.A. Larson (eds.). Tips on growing specialty potted crops. Ohio Florists' Assn., Columbus, OH.

Kimmins, R.K. 1992. Gloxinias, african violets, and other gesneriads, p. 290-293. In: R.A. Larson (ed.). Introduction to floriculture. 2nd ed. Academic Press, San Diego, CA.

Love, J.W. 1985. Commercial gloxinia production. North Carolina Agr. Ext. Serv. Hort. Info. Lflt. 539.

Pitchay, D.S. 2003. Impact of 11 elemental nutrient deficiencies on shoot and root growth, and foliar analysis standards of 13 ornamental taxa with emphasis on $\mathrm{Ca}$ and $\mathrm{B}$ control of root apical meristem development. North Carolina State Univ., Raleigh, PhD Diss. 1 May 2017. <http://www.lib. ncsu.edu/resolver/1840.16/5258>.

Williams, A.L. 2004. Foliar symptomology and tissue concentrations of five nutritionally deficient floriculture crops. North Carolina State Univ., Raleigh, MS Thesis. 